Cinémas

Revue d'études cinématographiques

Journal of Film Studies

\title{
Ouvrages reçus/Books Received
}

Volume 3, numéro 2-3, printemps 1993

URI : https://id.erudit.org/iderudit/1001203ar

DOI : https://doi.org/10.7202/1001203ar

Aller au sommaire du numéro

Éditeur(s)

Cinémas

ISSN

1181-6945 (imprimé)

1705-6500 (numérique)

Découvrir la revue

Citer ce document

(1993). Ouvrages reçus/Books Received. Cinémas, 3(2-3), 252-252.

https://doi.org/10.7202/1001203ar d'utilisation que vous pouvez consulter en ligne.

https://apropos.erudit.org/fr/usagers/politique-dutilisation/ 


\section{Ouvrages reçus/Books Received}

ALTMAN, Rick (ed.). Sound Theory, Sound Practice. New York : Routledge, 1992, xi $+290 p$.

BLACK, Joel. The Aesthetics of Murder: A study in Romantic Literature and Contemporary Culture. Baltimore : Johns Hopkins University Press, 1991, $x+276 p$.

BONDANELLA, Peter. The Cinema of Frederico Fellini. Princeton : Princeton University Press, 1992, xiii $+367 p$.

BRAUDY, Leo. Native Informant: Essays on Film, Fiction and Popular Culture. New York: Oxford University Press, 1991, $x+304 p$.

EVANS, Gary. In the National Interest: A Chronicle of the National Film Board of Canada from 1949 to 1989 . Toronto : University of Toronto Press, 1991, xvii + 407p.

GARDIES, André, BESSALEL, Jean. 200 mots-clés de la théorie du cinéma. Paris : Cerf, 1992, 225p.

HACKER, Jonathan, PRICE, David. Take 10. Contemporary British Directors. New York : Oxford University Press, 1991, x + 434p.

JAMES, David E. (Ed.). To Free the Cinema: John Mekas and the New York Underground. Princeton : Princeton University Press, 1992, 333p.

LEWIS, John. The Road to Romance and Ruin: Teen Films and Youth Culture. New York : Routledge, ix $+173 p$.

SKLAR, Robert. City Boys: Cagney, Bogart, Garfield. Princeton : Princeton University Press, 1992, xiii +311 p.

STAIGER, Janet. Interpreting Films: Studies in the Reception of American Cinema. Princeton : Princeton University Press, 1992, xiv + 274p.

STAM, Robert. Reflexivity in Film and Literature: From Don Quixote to Jean-Luc Godard. New York : Columbia University Press, 1992 [1985], xxi $+285 p$.

WEES, William C. Light Moving in Time: Studies in the Visual Aesthetics of Avant-Garde Film. Berkeley : University of California Press, 1992, xii $+199 p$. 